\title{
諫早湾干拓調整池流域における \\ 雨天時の污濁負荷流出量の予測 \\ PREDICTION OF POLLUTANT RUNOFF LOAD FROM BASINS \\ OF ISAHAYA FLOOD REGULATION POND UNDER THE RAIN CONDITION
}

\author{
西田 渉1・岩尾良太朗2 \\ Wataru NISHIDA, Ryotaro IWAO \\ 1正会員 博士 (工) 長崎大学准教授 大学院工学研究科（广852-8521 長崎県長崎市文教町1-14） \\ 2学生会員 長崎大学大学院工学研究科 総合工学専攻 (同上)
}

\begin{abstract}
Recently, the reduction of pollutant load from watershed becomes significant issue for the water quality management at a closed water area. Countermeasure for the nonpoint pollution load is urgently needed. In this study, to predict and estimate the amount of pollutant runoff from watershed under the rain condition, a numerical model was developed. The rainfall-runoff relation was calculated by the runoff function method, and the amount of pollutant-runoff was represented as the function of specific discharge. This model was applied to the prediction of the temporal variation of suspended solids (SS) at four rivers which are flowing into Isahaya flood regulation pond, Nagasaki. Computed results of the flood discharge and the runoff load of SS have good agreements with observed results, and the usefulness of this model was shown.
\end{abstract}

Key Words : rainfall runoff, pollutant load, lumped model, numerical simulation, suspended solids Isahay a flood regulation pond

\section{1.はじめに}

閉鎖性水域の水質を良好な状態に改善するためには, 水域内で発生寸る内部負荷の削減と共に，流入河川等を とおして流域からもたらされる外部負荷の抑制が必要で ある.ここで, 流域からの污濁負荷量については, 近年, 生活排水や事業所排水といった点源からの負荷量が減少 傾向にあるのに対して, 市街地や農用地等を発生源とす る非点源からの負荷削減は十分な状況に至っておらず, 全負荷量に占める割合が増す傾向にあるとされる ${ }^{1)}$ そ のため, 非点源からの污濁原因物質の流出量の把握と制 御方策の構築は益々重要になってきている.

本研究で取り上げる諫早湾干拓調整池は閉鎖性の強い 水域である. 当調整池では, 貯留水の水質の保全と改善 を目的とした各種の対策が実施されてきたものの，現在 までに設定された環境保全目標值を充足するには至って いない2)。水質が改善されない理由は慎重に検討されな ければならないが，流域から流出する污濁負荷量の把握 は，污濁物質の流入による調整池の水質の応答を適切に 評価し，より効果的な污濁負荷削減方策を選定，実行し
ていく上で不可欠である。ここでは，非点源負荷への対 応が大切になってきている状況を考慮し, 雨天時におけ る污濁負荷流出量の評価を目的とした予測手法の構築を 試みることにした. 雨天時の負荷流出量の評価について は，これまでに様々な手法が提案されており，目的に応 じて形式を選ばなければならないが，流域を空間的に一 括して取り扱う集中型モデルとして構成された。 これは, 分布型モデルに比べてパラメータ数が少なく十分な検定 によって実用的なモデルとさせやすいためである.また， モデルによる評価結果を調整池内の物質輸送を数值解析 する際の境界条件一利用しようと考えており，そうした 場合については，污濁物質の流域上での物理的流出過程 を重視しなくて良いと判断したことによっている. 本論 では計算対象の水質指標として浮遊懸濁物質(SS)を取り 上げている.

以下では，まず，諫早湾干拓調整池一の流入河川で行 われた観測結果に基づいてSS と他の水質項目との関連性 を述べる. 続いて, 本研究で用いた雨水流出モデルと污 濁負荷流出モデルについて説明する. 最後に, 構築した モデルの現地への適用を行い，実測值との比較をとおし てその適用性について検討する. 


\section{2. 雨天時における河川水の水質}

\section{（1）対象河川}

諫早湾干拓調整池の流域と河川の概要を図-1に示す. 全流域面積は $249 \mathrm{~km}^{2}$ であり，大小 10 以上の河川がある. ここでは，以前に行われた連続観測の結果を文献3)等で 参照可能な一級河川本明川と 3 本の二級河川(境川, 深海 川，二反田川をを対象河川に取り上げた．観測地点は図一 1のとおりであり，調整池の貯留水が河道流に影響しな い位置に取られている．各観測地点における流域面積は, 国土数值情報と地形図の読み取りから判別した結果から, 本明川: $38.3 \mathrm{~km}^{2}$ ，境川: $17.4 \mathrm{~km}^{2}$ ，深海川: $6.9 \mathrm{~km}^{2}$ ，二反田 川: $4.1 \mathrm{~km}^{2}$ である. 次節で示す結果は，2002(平成14)年以 降の観測によって得られており, 各地点での全観測回数 は，雨天時と晴天時を含めて，本明川: 5回，境川: 6回， 深海川: 7回，二反田川: 6回となっている.

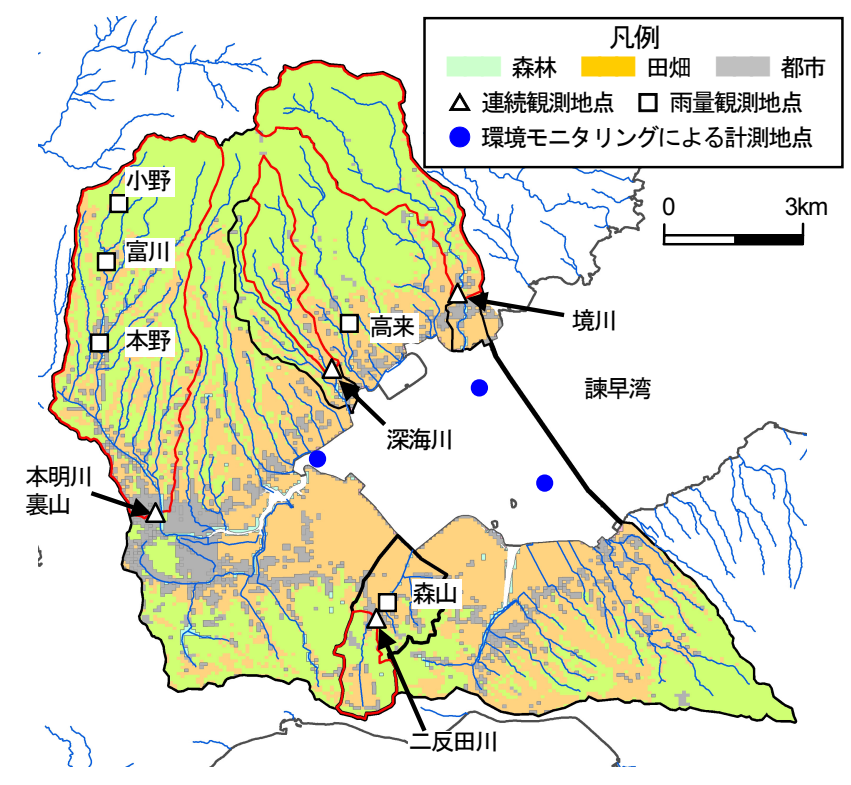

図-1＼cjkstart対象河川の流域と観測地点の位置図

\section{（2）SSと他の水質指標との関係}

各河川で観測されたSSについて，まず，化学的酸素要 求量(COD)並びに栄養塩(全窒素(TN), 全リン(TP))との 相関図と，各水質指標に対する回帰曲線を図-2に示す. 図に示された結果によると, 各指標の濃度とSSには正の 相関関係があり，SSに由来する成分の評価が水質変化の 解明に必要であるといえる. 相関の程度は河川や水質指 標毎に異なるが，SSとの相関はCODとTPで高く，TNで は低くなる傾向が見られる. 雨天時のSSの時間変化につ いては後で示すが，対象河川のSSの濃度は出水時に高く なる．このことを考慮して，SSが高濃度となっている データを取り上げてTPとSSの比率(TP/SS)を計算すると 約 $1 \sim 2 \mathrm{mgP} / \mathrm{g}$ であり，土壌中のリンの含有量に関する報
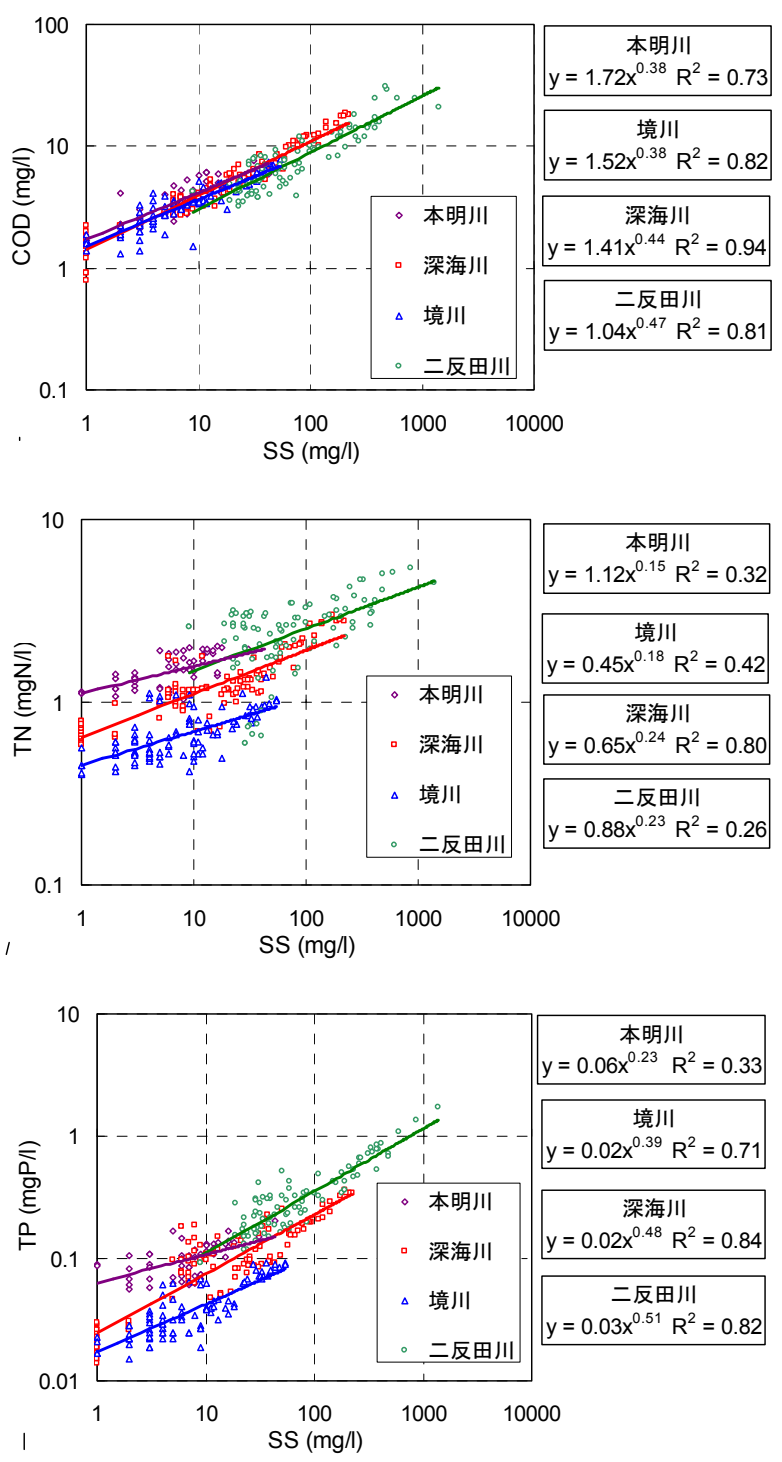

図-2ＳSとの相関関係図

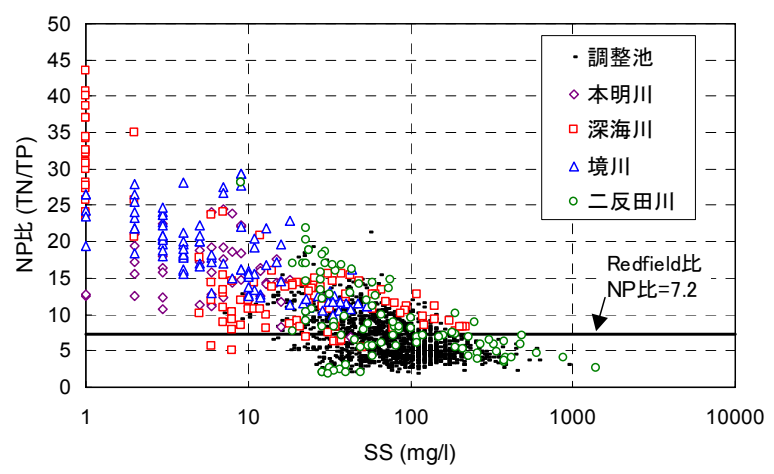

図-3 SSとNP比との関係図

告值 $(1.7 \sim 2.3 \mathrm{mgP} / \mathrm{g})^{4,5)}$ と同程度の值となっている. 本来 的には，現地試料を測定し比較しなければならないが, 雨水の出水に伴って流域から流出した懸濁成分が影響を 与えたものと推察される.

つぎに, 流出水中のTNと TPの構成比(NP比) と SSとの 関係を図-3に示す.この図には，調整池において2002 
(平成14)年以降に環境モニタリングとして計測された報 告值のを用いて算定した值を併記している．計測地点は 図-1に記したとおりであり，各地点の表層での結果であ る. 対象河川のNP比は, $\mathrm{SS}$ の濃度が低い場合に, ある $\mathrm{SS}$ 值に対する分布幅が広いが，SSの濃度が高くなるに つれて，その幅は狭まり，また，NP比は小さくなるよ うである.この傾向を植物プランクトンの細胞組成比を

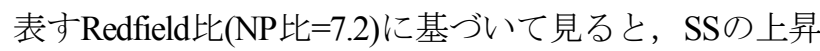
につれて, リン制限の程度が緩和される傾向にあるとい える. 調整池のNP比についてもSSの濃度に応じた同様 の変化傾向が見られる. とくに, 調整池のSSが $200 \mathrm{mg} / 1$ 程度を超える期間は洪水時に相当していることから，河 川からの洪水の流入は, 調整池内のSSの増加をとおして 水中の栄養塩の構成に少なからず影響を及ぼしているも のと推察される. 流出水のSS と水質との関連性について は検討を深め称ばならないが，対象河川のCODや栄養塩 の濃度は図-2に併記された回帰曲線を用いて評価され得 るものとして，ここでは，SSを計算対象に取り上げるこ とにした.

\section{3. 予測モデルの概要}

\section{（1）雨水流出モデル}

諫早湾干拓調整池一流入する河川に対しては, 集中型 と分布型のモデルによる流出解析事例があるが-9), 本研 究では，著者らが当調整池の流動予測の際に河川の洪水 流量の評価に利用している流出関数法を採用した. モデ ルの構成は既報10)で述べているので，ここでは概要を記 しておく.

雨水の流出解析にあたって，国土数值情報を参考に流 域の土地利用種別を都市領域，田畑領域，森林領域の3 種に大別し，各領域からの流出量を評価している．なお， 森林領域からの流出量については, 早い流出成分と遅い 流出成分の 2 成分を想定した. 今回の計算は短期流出と みなされる期間を対象としており，地下水流出成分は取 り上げていない，ここで，モデルで用いた流域内の土地 利用種別領域からの流出流量 $\left(Q_{j}(t)\right)$ の評価式は, 次のと おりである ${ }^{11}$.

$$
Q_{j}(t)=A_{j} \int_{0}^{t} f_{j}(t) r(t) H_{j}(t-\tau) d \tau
$$

ここに, $t$ : 時刻, $\tau$ : 流出の遅れ時間, $A_{j}$ : 土地利用種 別 $j$ の流域面積, $f_{j}(t)$ : 降雨の流出への寄与率, $r(t)$ : 実 測降雨量, $H_{j}(t):\left(=\alpha^{2} t \mathrm{e}^{-\alpha t}\right)$ 流出関数 $(\alpha$ は流出に関わる 係数), である. また, 降雨の流出については, 初期損 失量を課し, 降雨期間の累積雨量が一定量を超えた後に 始まるものとし，その後の降雨の流出一の寄与率を累積 雨量に応じて増加するとものとしている.

流域からの総流量 $(Q(t))$ は, 基底流量 $\left(Q_{b}\right)$ を一定值とし
て与え, $Q_{b}$ と先記の 3 種類の領域からの流出量の和 $\left(Q(t)=Q_{b}+\Sigma Q_{j}(t)\right)$ として評価している. 算定流量は各河 川の観測地点における量とみなしたので河道での洪水追 跡計算は行っていない.

\section{（2）污濁負荷流出モデル}

濁質の流出量は流域で発生している流れの状態に依存 するものとして取り扱い, 雨水流出モデルで算定される 比流量の関数として表すことにした. 寸なわち, 流域か らの比負荷流出量は比流量のべき乗に比例するものとし て基本評価量とおき, この量に基底流出量を加えて総負 荷流出量 $(L(t))$ を次式のとおりに評価した.

$$
L(t)=L_{b}+a q_{u}(t)^{b} \cdot g(m(t)) \cdot A
$$

ここに, $L_{b}:\left(=C_{b} Q_{b}\right)$ 基底負荷流出量, $C_{b}$ : 基底流中の濃 度, $q_{u}(t):(=Q(t) / A)$ 流域全体の比流量, $A$ : 全流域の面積, $a, b$ : 係数, である. なお, 係数 $a$ が負荷量の絶対量を決 め, 係数bが流出のされやすさに関わるとされる ${ }^{12)}$. 関 数 $g$ は, 対象にする水質項目によっては, 流出初期に高 濃度となるファーストフラッシュ現象が観測されること， また，洪水期間の負荷流出量と流量との関係が増水時と 減水時に異なるといった流量に対する負荷流出量の二価 性に対応させるために導入された項である.

関数 $\mathrm{g}$ 内容は式(3)のとおりである。この式において, ファーストフラッシュ現象に関しては, 他の解析例 13,14$)$ と同様に物質の流出限界を課した上で，比流量が流出限 界を超えた場合に基本評価量を上回る流出が生じる(関 数 $g>1$ ) ものと仮定した. 一方, 負荷流出量の二価性につ いては，継続的な流出によって流域面上の物質の存在割 合が減少することで污濁発生源からの流出がなされ難く なるものとし, 累積比負荷流出量がある量を超えると負 荷流出量が基本評価量を下回る(関数 $g<1$ )ものとした.

$$
g(m(t))= \begin{cases}c_{1}\left(1-\frac{m(t)}{m_{1}}\right)+1 & : m(t)<m_{1} \\ 1 & : m_{1} \leqq m(t) \leqq m_{2} \\ \left(\frac{m(t)}{m_{2}}\right)^{-c_{2}} & : m_{2} \leqq m(t)\end{cases}
$$

ここに, $m(t)$ : 累積比負荷流出量, $m_{l}$ : ファーストフ ラッシュの継続限界に関わる比負荷量, $m_{2}$ : 負荷流出量 の低減に関わる比負荷量, である. また, 係数 $c_{1}, c_{2}$ は, 前者がファーストフラッシュの基本評価量に対する濃度 の増加率を表し, 後者は負荷流出量の低減の程度を表す パラメータである. なお, 既存のモデルでは堆積負荷量 の収支式が別途立てられることがあるが，今回の計算対 象流域の堆積負荷量に関して十分な観測結果を持ち合わ せていないこと，また，計算から直接得られる量を用い ることで評価式系を閉じるように構成することを意図し たことから，本モデルでは上記のように累積比負荷流出 量の関数として取り扱うことにしている. 


\section{4. モデルの現地適用と考察}

\section{（1）計算条件}

対象河川は第2章で示した本明川と3本の二級河川であ る. 計算期間は，本明川については，洪水の流出初期の 水質観測結果が得られている2002(平成14)年10月31日〜 11月1日とした。他の河川に関しては，時間的に密な計 測がなされている2007(平成19)年7月4日を対象にした. 降雨量は，本明川を対象にした計算では国土交通省によ る小野, 富川, 本野の各観測所における報告值の平均值 を与えた. 境川と深海川の計算では高木観測所での報告 值を, 二反田川に対しては森山観測所での報告值を与え た. 各雨量観測地点は図-1に示すとおりである．基底流 量と基底濃度には，観測開始時の流量と濃度を一定值と して与えた。

\section{（2）雨水流出の計算結果}

各計算で雨水流出モデルに入力された $\alpha$ 值を表-1に まとめる．また，計算条件として与えたハイドログラフ とモデルで算定された流量八イドログラフを図-4に示寸

表-1 流出に関わる係数 $(\alpha)$ の値

\begin{tabular}{|l|c|c|c|c|c|}
\hline \multicolumn{2}{|l|}{ 領域種別 } & 本明川 & 境川 & 深海川 & 二反田川 \\
\hline \hline \multicolumn{2}{|l|}{ 都市 } & 0.20 & 0.125 & 0.3 & 0.3 \\
\hline \multicolumn{2}{|l|}{ 田畑 } & 0.15 & 0.08 & 0.08 & 0.09 \\
\hline \multirow{2}{*}{$\begin{array}{l}\text { 森 } \\
\text { 林 }\end{array}$} & 早い流出成分 & 0.05 & 0.05 & 0.03 & \multirow{2}{*}{0.028} \\
\cline { 2 - 5 } & 遅い流出成分 & 0.025 & 0.007 & 0.007 & \\
\hline
\end{tabular}

まず， $\alpha の$ 值は，森林領域，田畑領域，都市領域の順 で大きく評価された．この係数は，洪水到達時間と流出 高に関連しており, 一般に, 都市化の進展に伴って雨水 排水施設等の整備が進み，雨水が流出しや寸くなること を考えると，妥当な関係にあると思われる．なお，二反 田川に関しては, 最大流量発生後の減水が境川や深海川 に比べて速かったため，二反田川を対象にした計算では 森林からの流出量は一成分のみで表現されている.

つぎに，流量の計算結果について述べる．観測結果に よると, 最大流量は, 本明川と二反田川では最大時間雨 量が測定された後に，また，境川と深海川においては $5 \mathrm{~mm} / \mathrm{h}$ 降雨が二度目に測定された後に，それぞれ現れ ているが，これらの洪水の増水から減水までの変化過程 が本モデルによって計算されている，また，精度は河川 ごとに若干異なるが，実測された最大洪水流量と洪水到 達時間を許容できる誤差の範囲で予測できていると言え る. 領域種別毎の流出流量については, 流出初期の流量 は，いずれの結果も都市領域や田畑領域からの成分を主 とするが，最大流量の発生時刻付近以降には，森林から の流出成分も加わった流出流が生じるものとして評価さ
れた. こうした流出成分の時間的遷移は各土地利用領域 からの流出のしや寸さを考えると概ね妥当と思われるが， 計算精度の向上のためには，土地利用種毎に計測された より詳細な実測結果との比較を行う必要があると考えて いる.

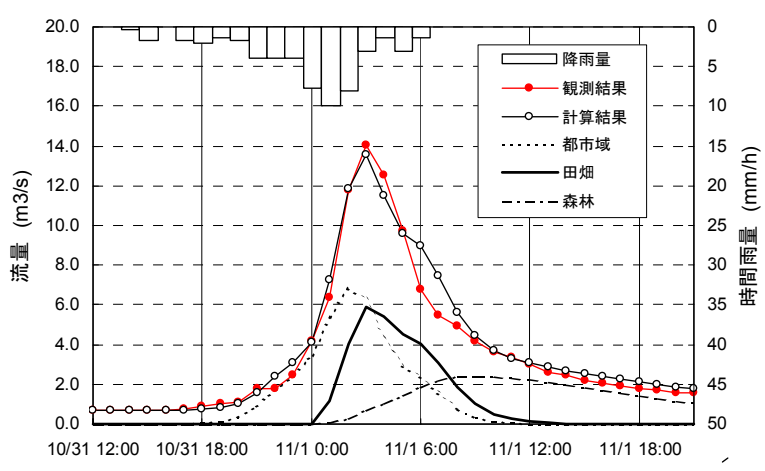

(a) 本明川 (2002 (平成14) 年10月31日 11月1日)
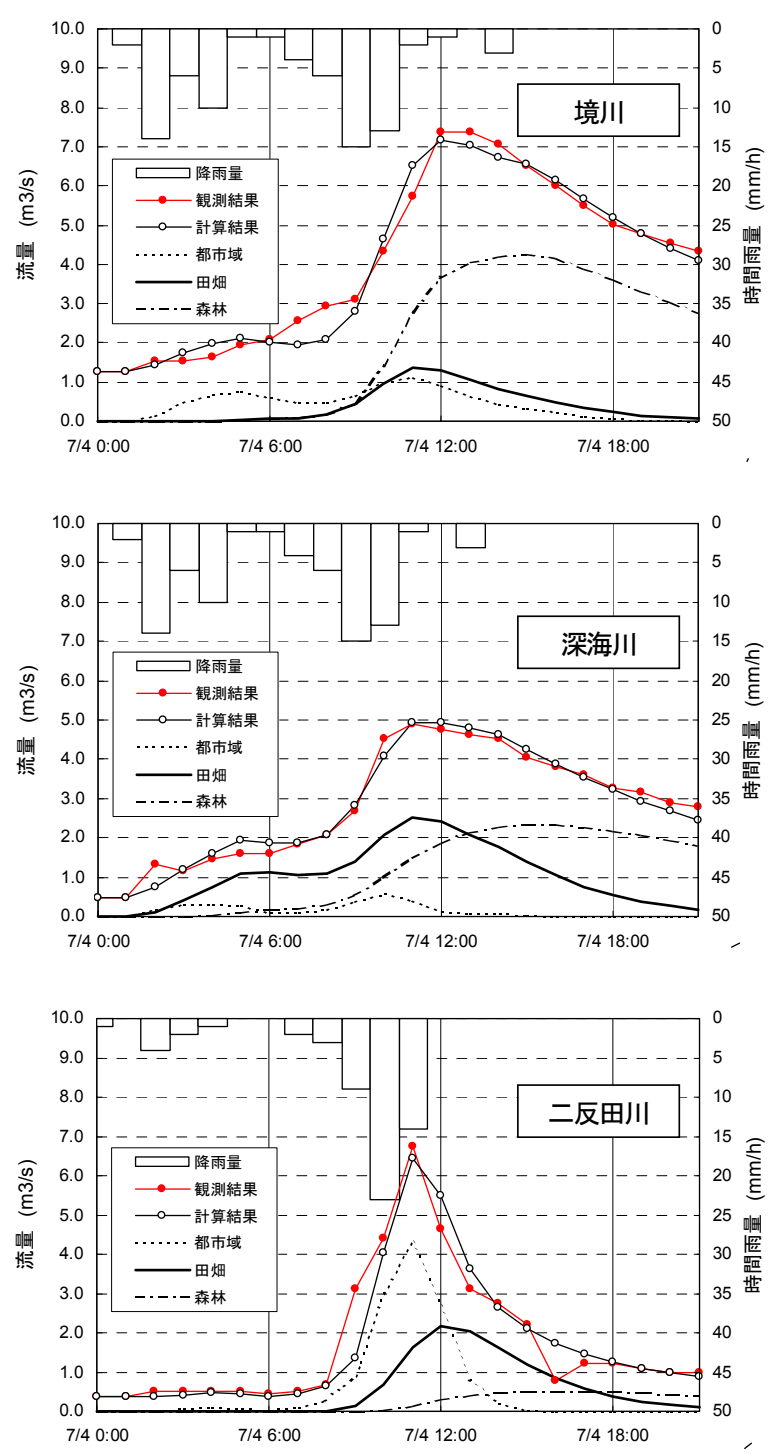

(b) 境川, 深海川, 二反田川(2007 (平成19) 年7月4日) 図-4＼cjkstart流量ハイドログラフ 


\section{（3）浮遊懸濁粒子の計算結果}

污濁負荷流出モデルによって算定されたSSの濃度と比 流量の時間変化を図-5に，流量と負荷流出量の関係を 図-6に示寸．また，モデル係数に設定された值を表-2に まとめる.

図-5に示された計算結果と観測結果を比較すると，計

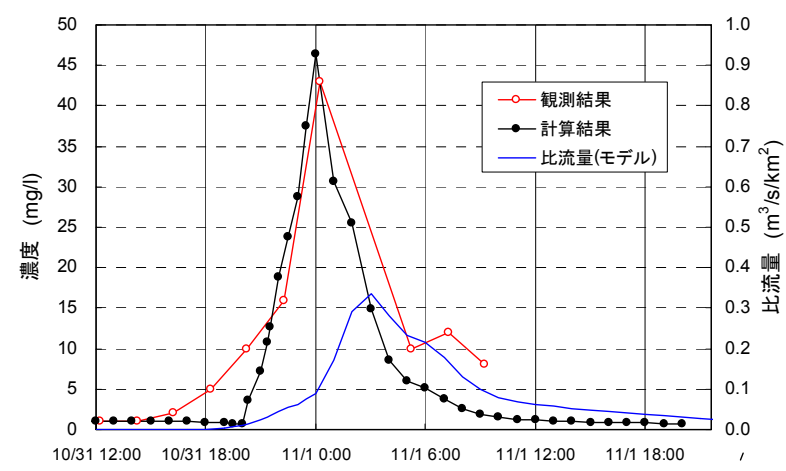

（a）本明川(2002(平成14) 年10月31日 11月1日)
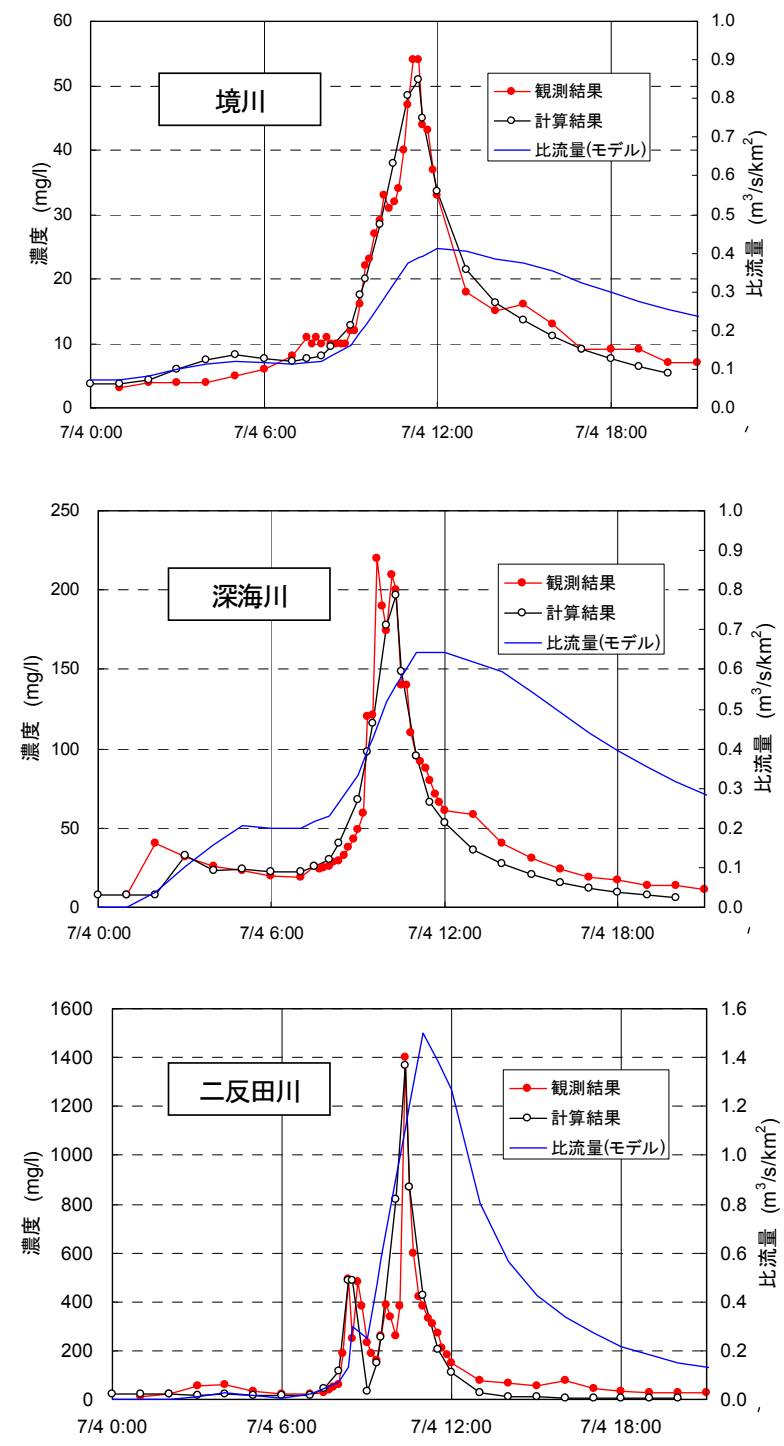

(b) 境川，深海川，二反田川(2007 (平成19) 年7月4日）

図-5 SSの時間変化

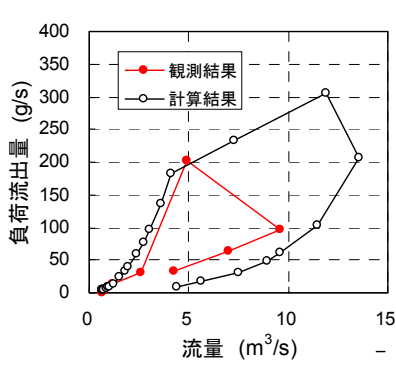

(a) 本明川

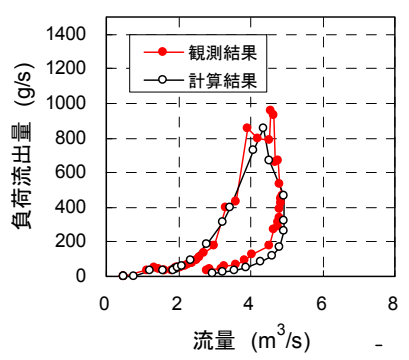

(c) 深海川

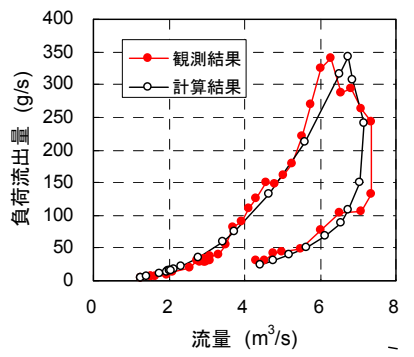

(b) 境川

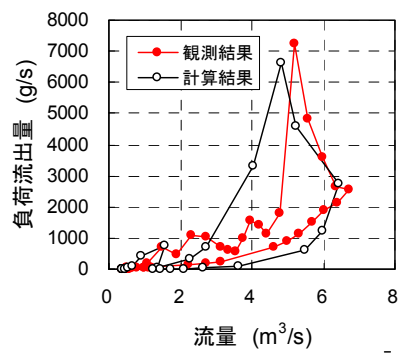

(d) 二反田川

表-2 負荷流出モデルのパラメータ值

\begin{tabular}{|c|c|c|c|c|}
\hline & 本明川 & 境川 & 深海川 & 二反田川 \\
\hline \hline$a$ & 782 & 318 & 793 & 1148 \\
\hline$b$ & 2.1 & 2.4 & 3.1 & 3.5 \\
\hline$m_{l}$ & 0 & 24 & 22 & 101 \\
\hline$c_{l}$ & 0 & 1.4 & 6.7 & 163 \\
\hline$m_{2}$ & 18 & 75 & 416 & 2066 \\
\hline$c_{2}$ & 1.7 & 1.2 & 2.3 & 2.3 \\
\hline
\end{tabular}

算結果は，負荷流出の末期における濃度を低く評価して いること，また，本明川に関しては出水時間中の実測値 が久測となっており最高濃度の算定精度の検証ができな いといった問題点があるが，本モデルは，観測結果に見 られる濃度の時間変化の全体的な傾向を表現しており, 比流量が急増する時間に発生した濃度の最高值と発生時 刻を精度良く予測できていると思われる. 二反田川につ いては，最高濃度が現れる約2時間前に生じたファース トフラッシュによると考えられる濃度の上昇が計算結果 に明瞭に表現されている. これらの結果を, 図-4に示し た流量の時間変化と併せて見ると, $\mathrm{SS}$ 最高濃度は, 森 林からの流出流量が最大となる以前に現れていることが 分かり，都市領域並びに田畑領域からの流出成分が主に なっているものと推察される. 図-6に示された流量と負 荷流出量との関係に関しては, 濃度並びに流量の算定誤 差に起因した違いがあり，また，本明川の結果について は先記の理由のために計算された最大負荷流出量の妥当 性を判断し難いが，流量と負荷流出量の関係は，観測結 果と同様に，全て右回りのループとして評価されており， 本モデルによって負荷流出量の流量に対する二価性が良 好に表現されていると思われる. 
モデル係数の值については，係数bは2を超えているこ とから，比流量の増加に応じて負荷流出量が急増寸る状 態にあり， $b$ の值からは，SSの発生要因に洗い出し型 $\left.(b>1)^{15}\right)$ の流出特性があるものと判断される. なお，係数 $a, b$ は, 森林域において, $a=$ 数百〜十数万, $b=3 \sim 6$ との 報告がある ${ }^{12}$. 当計算領域には都市域と田畑域を含むの で, 值の比較には注意が必要であるが, 報告值程度と なっている．一方， $m_{1}$ と $m_{2}$ は，二反田川の $m_{2}$ の值が大 きいが，これは，負荷流出量が当河川において最も多く， 負荷流出量が基本評価量を下回り始めるまでに相応量の 累積的負荷流出がなされねばならないためである. なお, 本明川については，顕著なファーストフラッシュはな かったものとみなし, $m_{1}$ は零とされた.

以上から, 本研究で構築されたモデルの現地一の適用 性がある程度示されたものと考えている. モデル係数に 関しては，観測された流量やSS濃度の時間変化を再現し 得る值として評価されているが，それらの妥当性を高め るためには，多くのデータに基づいた検証が必要である。 また，SSとの相関が低かったTNについては，現地観測 をとおして，その動態把握に努め，適切なモデル化に取 り組む必要がある。

\section{5. おわりに}

本研究では，雨天時における流域からの短期的污濁負 荷流出量の評価を目的として, 雨水流出モデルと污濁負 荷流出モデルで構成される予測モデルの構築を試みた. また, 諫早湾干拓調整池への流入河川を対象に取り上げ て, 本モデルの適用性を検討した. 計算対象の污濁物質 としては，CODやTPとの間に強い相関が見られたSSを 取り上げている.

計算結果と観測結果との比較から, 雨水流出モデルと 污濁負荷流出モデルは簡便な形式で構成されているもの の, 流量の時間変化を始めとして, ファーストフラッ シュ現象や負荷流出量の二価性現象が表現されており, 今回のSSの時間変化を概ね再現可能であることが示され たと考えている. ただし，算定されたSSの流出負荷量は, 二つのモデルの計算結果に起因した誤差を生じるため, 予測精度の向上にあたっては，検証を十分に行う必要が ある.また，閉鎖性水域の水質予測にあたっては，長期 的な負荷流出量の把握と窒素系污濁物質の流出量評価が 重要であり, 今後, これらの課題しついても検討してい きたいと考えている.

謝辞 : 本研究の遂行にあたり参照した実測值は，長崎大 学名誉教授 野口正人先生をはじめとして, 当時研究室 所属の学生諸氏, 関係各位のご努力によって得られてい る.ここに記して深謝申し上げます，また，流域界の現 地調査と計算用データの作成に協力頂いた平成 23 年度の
河川環境研究室の4年生 松本崇寛氏, 美馬由佳氏に感 謝申し上げます.

\section{参考文献}

1）国土交通省，農林水産省，環境省：湖沼水質のための流域 対策の基本的考え方〜非特定污染源からの負荷対策〜, p. 36 , 2006.

2) 長崎県: 第 2 期諫早湾干拓調整池水辺環境の保全と創造の ための行動計画, p.21, 2008.

3) 北島雄太, 田中晃司, 松永 学, 野口正人, 西田 涉, 鈴 木誠二 : 諫早湾調整池における降雨時の非点源污濁負荷流出 量の予測と評価に関寸る研究, 長崎大学工学部研究報告, Vol.38, No.70, pp.38-43, 2008.

4) 佐藤敦久編著: 水環境工学 浮遊物質からみた環境保全, 技法堂出版, pp.39-43, 2008.

5) 西村文武，菅谷真美，赤瀬孝也，増田理子，渡邊政広，津 野 洋: 相橘類果樹園地からの流出水水質特性に関する調查 研究，水工学論文集，Vol.52, pp.1135-1140, 2008.

6) 農林水産省九州農政局ホームページ資料: 諫早湾干拓事業, (http://www.maff.go.jp/kyusyu/nn/isahayaindex.html).

7) Tahat H.M.M., Noguchi M., Nishida W. and Hanada H.: The sensitivity of a physically-based rainfall-runoff model to the physiographic factors of real basin, Ann. J. of Hyd. Eng., JSCE, Vol.39, pp.37-42, 1995.

8) 野口正人, 西田 渉, 姜 相赫, 水野良宣, 矢代まゆみ：降 雨時における流域からの非点源污濁負荷流出機構の解明とそ のモデル化に関する研究，水工学論文集，Vol.45, pp.61-66, 2001.

9) 野村佐和美, 野口正人, 西田 涉, 水野良宣 : GISデータを 用いた非点源污濁負荷流出量の予測と評価, 水工学論文集, Vol.47,pp.1021-1026, 2003.

10) 西田 涉, 鈴木誠二, 岩尾良太朗, 池永雄太 : 諫早湾干拓 調整池における降雨時の流れの予測に関寸る研究，土木学会 論文集B1(水工学), Vol.68, No.4,pp.I_793-I_798, 2012.

11) 呉 修一, 山田 正, 吉川秀夫 : 有効降雨の推定に関する 研究，土木学会論文集B, Vol.65, No.3, pp.231-245, 2009.

12) 山田俊郎, 清水達雄, 井上隆信, 橘 治国 : 降雨時におけ る森林集水域加の水質成分負荷流出特性, 環境工学研究論 文集，Vol.36,pp.217-224, 1999.

13) 和田安彦, 三浦浩之 : 分流式下水道の雨水流出に伴う污濁 負荷流出モデルとその適用，土木学会論文集，No.369/II-5, pp.287-293, 1986.

14) 肱岡靖明, 古米弘明 : 都市ノンポイント污染源負荷流出調 查に基づく不浸透面堆積負荷流出モデルの検討，土木学会論 文集，No.685/VII-20, pp.123-133, 2001.

15) 山田俊郎, 大江史恵, 清水達雄, 橘 治国 : 森林集水域か らの栄養塩負荷流出とその特性に関する比較研究, 環境工学 研究論文集, Vol.35, pp.85-93, 1998.

(2012. 9. 30受付) 